\title{
Wood anatomy of Korean Symplocos Jacq. (Symplocaceae)
}

\author{
Balkrishna GHIMIRE, Beom Kyun PARK, Seung-Hwan OH, \\ Jaedong LEE ${ }^{1}$ and Dong Chan SON* \\ Division of Forest Biodiversity, Korea National Arboretum, Pocheon 11186, Korea \\ ${ }^{1}$ Division of Biological Sciences, Jeonbuk National University, Jeonju 54896, Korea \\ (Received 25 June 2020; Revised 16 September 2020; Accepted 23 September 2020)
}

\begin{abstract}
Despite poorly documented species delimitation and unresolved taxonomic nomenclature, four species of Symplocos (S. coreana, S purnifolia, S sawafutagi, and S. tanakana) have been described in Korea. In this study, we carried a comparative wood anatomy analysis of all four species of Korean Symplocos to understand the wood anatomical variations among them. The results of this study indicated that Korean Symplocos are comparatively indistinguishable in terms of their qualitative wood features, except for exclusively uniseriate rays present in S. purnifolia instead of uniseriate to multiseriate in other three species. Nevertheless, differences are noticed in quantitative wood variables such as the vessel density, vessel size, and ray density. The vessel density of $S$. purnifolia is more than twice as high as those of S. sawafutagi and S. tanakana. In contrast, the vessel circumference and diameter on both plants of S. sawafutagi and S. tanakana is nearly twice as large as those of S. purnifolia. Symplocos coreana has characteristic intermediacy between these two groups in terms of vessel features and is closer to $S$. purnifolia in terms of its ray density level. A cluster analysis based on a paired group (unweighted pair-group method with the arithmetic mean, UPGMA) algorithm using the Euclidean similarity index clearly differentiates S. purnifolia from the remaining species, representing the first branch of the phenogram.
\end{abstract}

Keywords: wood anatomy, Symplocos, taxonomy, UPGMA

Symplocos Jacq. comprising about 350 species is the sole isolated genus of the family Symplocaceae (Fritsch et al., 2008). The species are mostly evergreen or sometimes deciduous, shrubs or trees with widespread distribution in moist tropical to the subtropical region of India through Southeast Asia and Malesia to northeastern Australia, and America (Cronquist, 1981). Although the family is well recognized, its systematic position within the order Ericales is still ambiguous (Caris et al., 2002). In the recent molecular analyses, the family has been positioned as sister to a clade comprising Diapensiaceae and Styraceae (Schönenberger et al., 2005). The distinguishing features of the family include the combination of leaves without stipules, sympetalous actinomorphic flowers; epipetalous, united, and usually numerous stamens with spheroid thecae; an inferior, incompletely locular ovary, a simple style; unitegmic ovule; and a drupaceous fruit (Nooteboom, 2003).
In the comprehensive taxonomic revision of Symplocos, Brand (1901) divided the genus into four subgenera: Eusymplocos Brand, Epigenia (Vell.) Brand, Hopea (L. f.) C. B. Clarke, and Microsymplocos Brand. Later, Nooteboom (1975) treated Epigenia and Microsymplocos within Hopea, recognizing only two subgenera, but Nagamasu (1993) again treated Microsymplocos as an independent subgenus endemic to South America. Only two subgenera Symplocos (with Monadelphous stamens) and Hopea (with pentadelphous or free stamens) have been reported in Asia (Nooteboom, 1975; Nagamasu, 1993). Despite poorly documented species delimitation and unresolved taxonomic nomenclature four species of Symplocos (S. coreana (H. Lev.) Ohwi, S sawafutagi Nagam., S. tanakana Nakai, and S purnifolia Siebold \& Zucc.) have been described in Korea (Chang et al., 2011; Korea National Arboretum, 2017; Kim and Kim, 2018). These four species belong to two sections, Palura G. Don (S. coreana, $S$.

\footnotetext{
*Author for correspondence: sdclym@korea.kr
} 
sawafutagi, and S. tanakana) and Lodhra G Don. (S. purnifolia), of subgenus Hopea (Nagamasu, 1993; Soejima and Nagamasu 2004).

Wood anatomical features can provide useful information to resolve the phylogenetic relationships among and within the genera of angiosperms and gymnosperm (Oskolski, 1994, 1995; Baas et al., 2000; Oskolski and Lowry, 2000; Visscher and Jagels, 2003; Lens et al., 2007; Esteban and de Palacios, 2009). However, due to the insufficient knowledge of the microscopic structure of wood among the plant taxonomists, the studies incorporating wood features in phylogenetic analysis are very limited (e.g., Baas et al., 1988; Zhang, 1992; Gasson, 1994, 1996; Noshiro and Baas, 1998; Klaassen, 1999; Olson, 2002; Malécot et al., 2004; Lens et al., 2007). In addition, the wood anatomy of Symplocos is scarce in the modern literatures. Yamauchi (1979) reported the wood anatomy of nine species of Japanese Symplocos while van den Oever et al. (1981) carried the comparative wood anatomy of 31 Symplocos species in relation to latitude and altitudinal variations. More recently, Wang and Ou (2003) described the wood anatomy of 27 Symplocos taxa from Taiwan and Lens et al. (2007) included only two species of Symplocos in the role of wood anatomy in phylogeny reconstruction of Ericales. In this study, we carried the comparative wood anatomy of all the four species of Korean Symplocos. The primary objectives of the study are as follows: (1) to provide an overview of wood anatomical variation within Korean Symplocos species, and (2) to identify the systematic significance of wood features in the Symplocos.

\section{Materials and Methods}

\section{Light microscopy}

Mature branches were collected from natural populations. Names of the studied taxa, voucher number, and collection sites are presented in Table 1. Collected wood materials were preserved in $50 \%$ ethyl alcohol before section. Preserved wood samples were cut into approximately $2 \mathrm{~cm}$-long circular blocks. For microtome sectioning, the samples were prepared depending on the size of wood; cubic pieces were cut (transverse) or split (radial and tangential) from circular blocks. Three such pieces - representing three planes: transverse, radial, and tangential — of each sample were prepared. The blocks were preserved in softener solution (glycerin 10 parts/10\% aerosol OT 3 parts/distilled water 87 parts) until sectioning and were sectioned according to the standard technique for light microscopy. At least five permanent slides of each species including all three planes of wood in a single slide were prepared for the observation.

After preparing permanent slides, microscopic observations and wood-feature analyses were carried out under an AXIO Imager A1 light microscope (Carl Zeiss, Jena, Germany). We studied several quantitative and qualitative features of the wood structure and pertinent features of them are summarized in Table 2. Observations and measurements of the quantitative features of vessels, fibers, and rays were made with a Hirox 3D microscope and software therein (Hirox, Tokyo, Japan). At least $10-15$ cells from each of five slides (at least $50-70$ cells for each species) were measured for statistical analysis. Mean values for each feature were calculated from the measurements taken from the same species but different samples and standard deviations were also calculated. Photographs of the best sections with characteristic features were taken using a digital camera system attached to the light microscope.

\section{Statistical analysis}

The biometric data were analyzed statistically. For each wood features, one-factor analysis of variance (ANOVA) was used to examine differences in means among the included species. Pearson's correlation coefficients were used to estimate the relationship among the vessel number, vessel diameter, vessel fibers wall thickness, bordered pit, ray number, and ray thickness. All of the statistical analyses were carried out using the SPSS statistical program (IBM SPSS Statistics for Windows version 20.0., IBM Corp., Armonk, NY, USA). The cluster analysis based on the paired group (unweighted pair-group method with arithmetic mean, UPGMA) of seven quantitative characters were also performed to understand the significance of wood features for species delimitation by using the statistical program PAST ver. 4.02 (Hammer et al., 2001).

Table 1. Name of species and collection information.

\begin{tabular}{lccc}
\hline \hline \multicolumn{1}{c}{ Taxon } & Korean name & Voucher No. & Collection site \\
\hline Symplocos sawafutagi Nagam. & 노린재나무 & EKS20180911-001 & Pyeongchang-gun, Gangwon-do \\
Symplocos tanakana Nakai & 검노린재나무 & EKS20180925-001 & Shinan-gun, Jeollanam-do \\
Symplocos coreana (H. Lev.) Ohwi & 섬노린재나무 & SN20181024-001 & Miaksan, Seogwip-si, Jeju-do \\
Symplocos purnifolia Siebold \& Zucc. & 검은재나무 & SN20181024-004 & Sanghyo-dong, Seogwip-si, Jeju-do \\
\hline
\end{tabular}


Table 2. Comparative wood features of four Symplocos species.

\begin{tabular}{|c|c|c|c|c|}
\hline Distinguishing characteristic features & S. sawafutagi & S. tanakana & S. coreana & S. purnifolia \\
\hline Growth rings & Distinct & Distinct & Distinct & Distinct \\
\hline Wood & Diffuse-porous & Diffuse-porous & Diffuse-porous & Diffuse-porous \\
\hline Vessel arrangement & Radial pattern & Radial pattern & Radial pattern & Radial pattern \\
\hline Vessels & Solitary & Solitary and in a pair & Solitary and a group of $2-3$ & Solitary and a group of $2-4$ \\
\hline Vessel outline & Oval/rounded & Oval/rounded & Oval/rounded & Oval/rounded/angular \\
\hline Perforation plates & Scalariform & Scalariform & Scalariform & Scalariform \\
\hline Inter-vessel pits & Scalariform to opposite & Scalariform to opposite & Scalariform to opposite & Scalariform to opposite \\
\hline Spiral thickenings in vessel elements & Absent & Absent & Absent & Present \\
\hline Vessel density & $69-93$ & $81-100$ & $95-135$ & $160-215$ \\
\hline Vessel ray pitting & Reduced borders, pits rounded & Reduced borders, pits rounded & Reduced borders, pits rounded & Reduced borders, pits rounded \\
\hline Septate fibers & Absent & Absent & Absent & Absent \\
\hline Fiber pits & $\begin{array}{c}\text { Common on radial and tangential } \\
\text { walls }\end{array}$ & $\begin{array}{c}\text { Common on radial and tangential } \\
\text { walls }\end{array}$ & $\begin{array}{c}\text { Common on radial and tangential } \\
\text { walls }\end{array}$ & $\begin{array}{c}\text { Common on radial and tangential } \\
\text { walls }\end{array}$ \\
\hline Spiral thickenings in fiber cells & Absent & Absent & Absent & Present \\
\hline Axial parenchyma & $\begin{array}{l}\text { Scanty diffuse and scanty } \\
\text { paratracheal }\end{array}$ & $\begin{array}{l}\text { Scanty diffuse and scanty } \\
\text { paratracheal }\end{array}$ & $\begin{array}{l}\text { Scanty diffuse and scanty } \\
\text { paratracheal }\end{array}$ & $\begin{array}{l}\text { Scanty diffuse and scanty } \\
\text { paratracheal }\end{array}$ \\
\hline Ray width & Uniseriate to triseriate & Uniseriate to triseriate & Uniseriate and biseriate & Exclusively uniseriate \\
\hline Ray in radial section & $\begin{array}{c}\text { Body cells procumbent with mostly } \\
2-4 \text { rows of upright and square } \\
\text { marginal }\end{array}$ & $\begin{array}{l}\text { Body cells procumbent with mostly } \\
2-4 \text { rows of upright and square } \\
\text { marginal }\end{array}$ & $\begin{array}{c}\text { Body cells procumbent with mostly } \\
2-4 \text { rows of upright and square } \\
\text { marginal }\end{array}$ & $\begin{array}{l}\text { Procumbent and square cells mixed } \\
\text { throughout the ray }\end{array}$ \\
\hline Ray frequency & $38-46$ & $38-51$ & $28-39$ & $29-38$ \\
\hline
\end{tabular}


Table 3. Wood variables of four Symplocos species.

\begin{tabular}{|c|c|c|c|c|c|c|c|}
\hline Taxon & "VN $\left(/ \mathrm{mm}^{2}\right)$ & $\overline{\mathrm{VC}}(\mu \mathrm{m})$ & "VD1 $(\mu \mathrm{m})$ & "VD2 $(\mu \mathrm{m})$ & $\overline{\mathrm{TW}}(\mu \mathrm{m})$ & " RN $\left(/ \mathrm{mm}^{2}\right)$ & $\overline{\mathrm{BP}(\mu \mathrm{m})}$ \\
\hline S. sawafutagi & $\begin{array}{c}83.09 \pm 7.8 \\
(69-93)\end{array}$ & $\begin{array}{c}149.31 \pm 26.2 \\
(106.5-190.9)\end{array}$ & $\begin{array}{c}57.95 \pm 8.71 \\
(41.4-74.7)\end{array}$ & $\begin{array}{c}48.85 \pm 6.03 \\
(35-62.1)\end{array}$ & $\begin{array}{r}4.53 \pm 0.6 \\
(3.2-5.7)\end{array}$ & $\begin{array}{l}42.27 \pm 2.57 \\
\quad(38-46)\end{array}$ & $\begin{array}{c}4.88 \pm 0.42 \\
(3.9-5.5)\end{array}$ \\
\hline S. tanakana & $\begin{array}{c}90.91 \pm 5.8 \\
(81-100)\end{array}$ & $\begin{array}{c}150.44 \pm 19.46 \\
(103.5-185.3)\end{array}$ & $\begin{array}{r}57.42 \pm 7.27 \\
(41.8-70.9)\end{array}$ & $\begin{array}{c}42.52 \pm 5.08 \\
(34.8-56)\end{array}$ & $\begin{array}{r}3.75 \pm 0.7 \\
(2.6-5.2)\end{array}$ & $\begin{array}{c}44.91 \pm 3.64 \\
\quad(38-51)\end{array}$ & $\begin{array}{c}4.78 \pm 0.44 \\
(3.8-5.6)\end{array}$ \\
\hline S. coreana & $\begin{array}{c}111.64 \pm 11.02 \\
(95-135)\end{array}$ & $\begin{array}{c}124.82 \pm 11.78 \\
(102.4-145.6)\end{array}$ & $\begin{array}{l}56.11 \pm 8.62 \\
(32.2-68.9)\end{array}$ & $\begin{array}{c}42.87 \pm 6.2 \\
(30-54.7)\end{array}$ & $\begin{array}{c}4.18 \pm 0.68 \\
(3.1-5.5)\end{array}$ & $\begin{array}{c}33.27 \pm 2.86 \\
(28-39)\end{array}$ & $\begin{array}{c}5.08 \pm 0.43 \\
(4.1-5.7)\end{array}$ \\
\hline S. purnifolia & $\begin{array}{c}198.09 \pm 16.98 \\
(160-215)\end{array}$ & $\begin{array}{c}79.47 \pm 7.37 \\
(68-92)\end{array}$ & $\begin{array}{c}28.75 \pm 3.06 \\
(23.3-34.1)\end{array}$ & $\begin{array}{l}24.28 \pm 3.2 \\
(19.2-31.5)\end{array}$ & $\begin{array}{c}3.99 \pm 0.58 \\
(2.9-5.2)\end{array}$ & $\begin{array}{c}34 \pm 3.1 \\
(29-38)\end{array}$ & $\begin{array}{c}5.44 \pm 0.56 \\
(4.5-6.6)\end{array}$ \\
\hline ANOVA & $\begin{array}{l}F=243.7 \\
p<0.001\end{array}$ & $\begin{array}{l}F=87.58 \\
p<0.001\end{array}$ & $\begin{array}{l}F=95.46 \\
p<0.001\end{array}$ & $\begin{array}{c}F=102 \\
p<0.001\end{array}$ & $\begin{array}{c}F=6.2 \\
p<0.01\end{array}$ & $\begin{array}{l}F=39.98 \\
p<0.001\end{array}$ & $\begin{array}{l}F=10.38 \\
p<0.001\end{array}$ \\
\hline
\end{tabular}

VN, vessel number; VC, vessel circumference; VD1, vessel diameter parallel to ray; VD2, vessel diameter perpendicular to ray; TW, tracheid wall thickness; RN, ray number; BP, bordered pit.

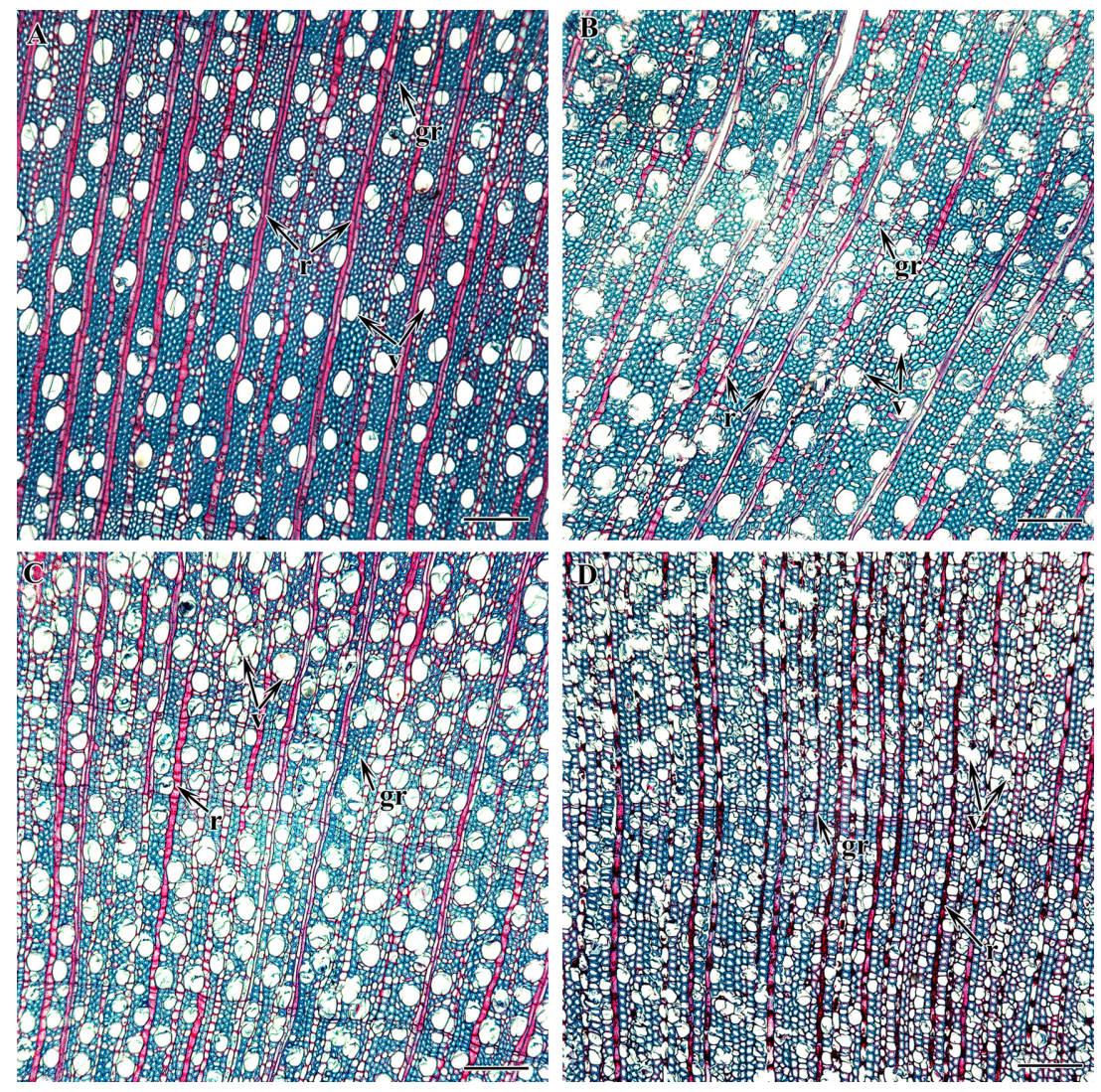

Fig. 1. Cross section of Symplocos wood showing growth ring, vessels, fibers, and rays. A. S. tanakana. B. S. sawafutagi. C. S. coreana. D. S. purnifolia. gr, growth ring; r, rays; v, vessel lumen. Scale bars $=250 \mu \mathrm{m}$.

\section{Results}

The comparative wood anatomy of four species of Korean Symplocos was carried out in this study. The qualitative wood features and quantitative wood variables of all the taxa are presented in Tables 2 and 3. Figs. 1-5 show the detailed wood features in the cross, radial, and tangential sections. All the taxa included have well-defined growth rings with the gradual transition of late and earlywood (Fig. 1A-D). In all four species, the quantity of late wood is very small with narrow and tangentially elongated fibers whereas early wood is large with thick-walled oval, rounded, and angular fibers. The wood is diffuse-porous. The vessels are radially arranged and exclusively solitary (S. sawafutagi), solitary and in a pair $(S$. 

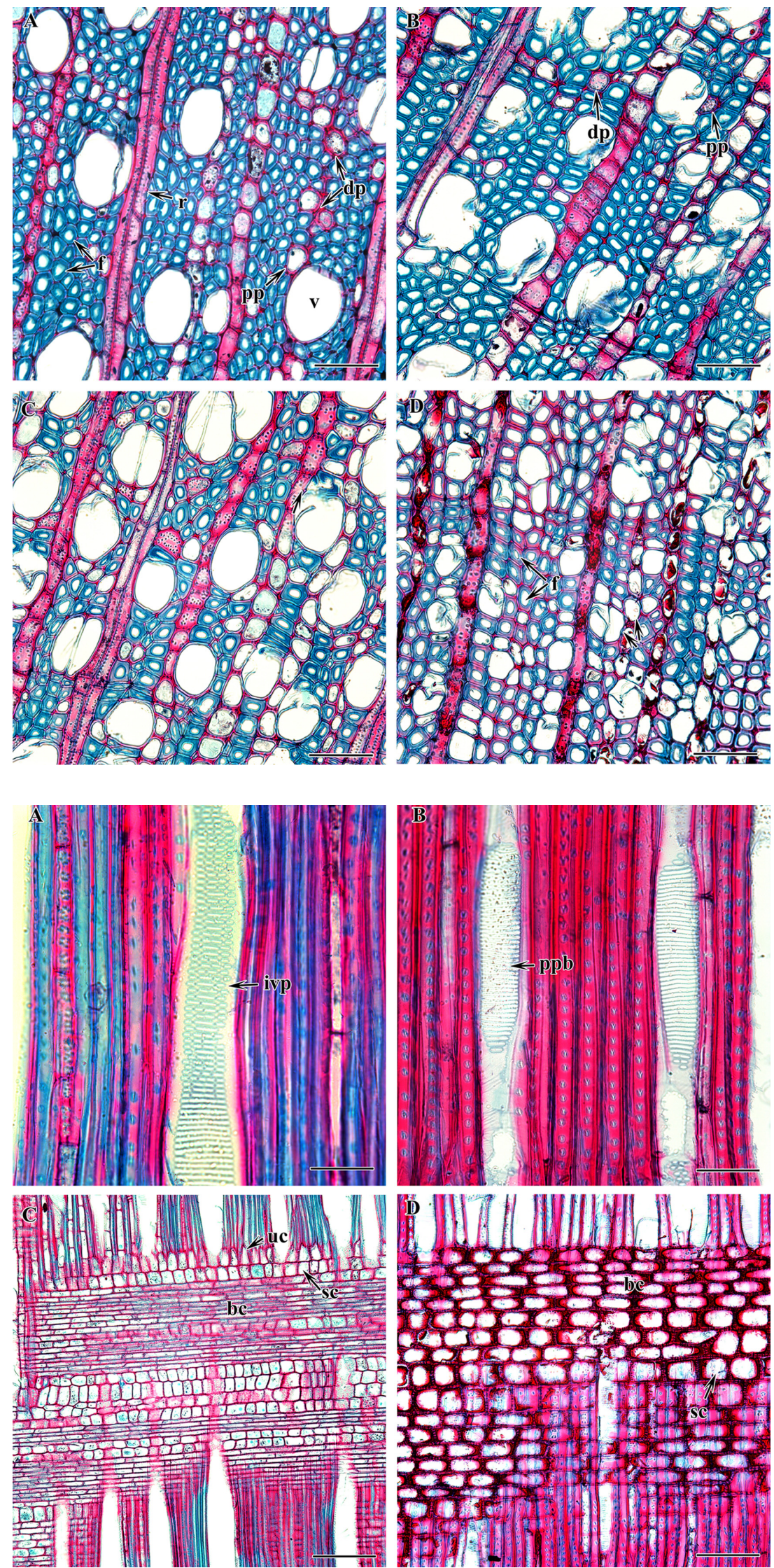

Fig. 2. Cross section of Symplocos species showing axial parenchyma (magnified). A. $S$. tanakana. B. S. sawafutagi. C. S. coreana. D. S. purnifolia (double arrow group of vessels). dp, diffused parenchyma; f, fibers; pp, paratracheal parenchyma cell; r, ray; v, vessel. Scale bars $=$ $50 \mu \mathrm{m}$.
Fig. 3. Radial longitudinal section (RLS) of Symplocos wood showing inter vessel pits, scalariform perforation plates, and ray cells. A. Scalariform and opposite inter vessel pits in $S$. tanakana. B. Scalariform perforation plates in $S$. purnifolia. C. Three types (upright, rectangular, and square) of ray cells in S. coreana. D. Two types (rectangular and square) of ray cells in $S$. purnifolia. bc, body cells of the ray; ivp, intervessel pits; ppb, bars on perforation plate; sc, square cells of the ray; uc, upright cells of the ray. Scale bars $=50 \mu \mathrm{m}$. 


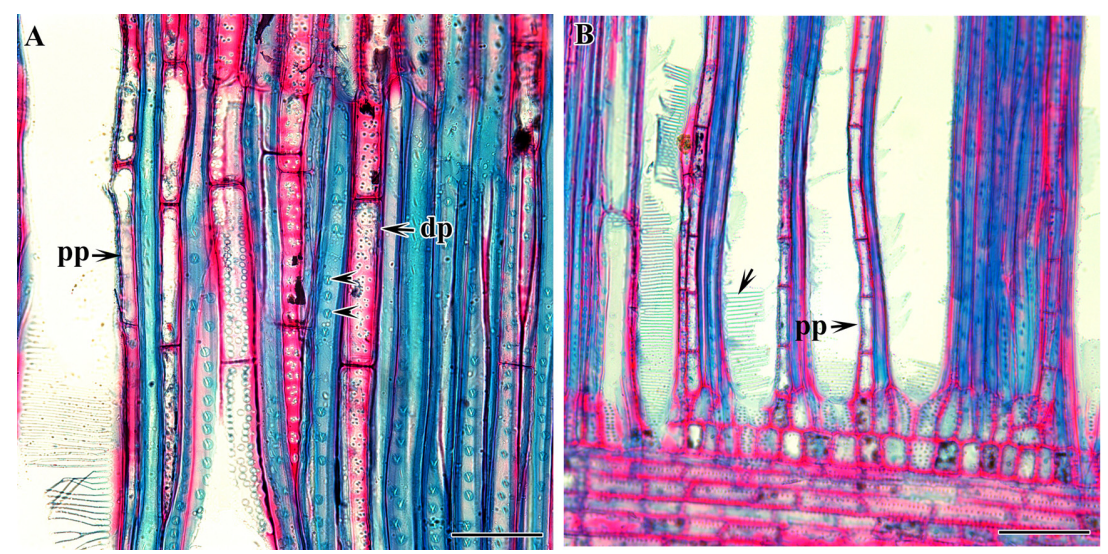

Fig. 4. Radial longitudinal section (RLS) of Symplocos wood showing axial parenchyma and bordered pits. A. RLS of S. sawafutagi showing diffused and paratracheal parenchyma (double arrowhead indicating bordered pits). B. RLS S. tanakana showing paratracheal parenchyma (arrow indicating bars of perforation plate). dp, diffused parenchyma; pp, paratracheal parenchyma; ivp, inter-vessel pits; v, vessel. Scale bars $=50 \mu \mathrm{m}$.

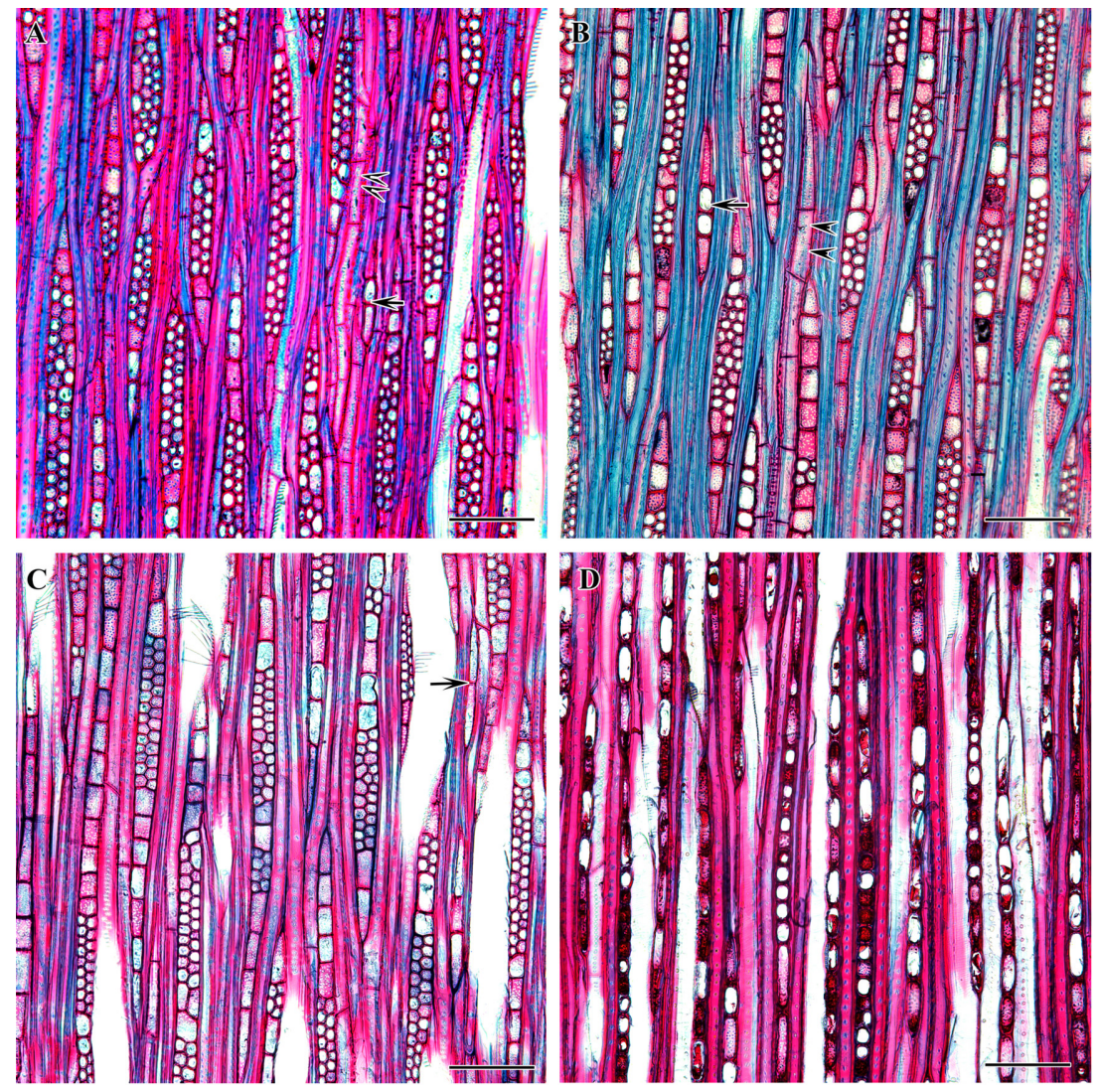

Fig. 5. Tangential longitudinal section (TLS) of Symplocos wood showing ray and parenchyma. A. TLS of S. tanakana showing uniseriate and multiseriate rays (single arrow indicating uniseriate ray and double arrow head indicating septate parenchyma). B. TLS of $S$. sawafutagi showing uniseriate and multiseriate rays (single arrow indicating uniseriate ray and double arrow head indicating septate parenchyma). C. TLS of S. coreana showing uniseriate and multiseriate rays (single arrow indicating uniseriate ray). D. TLS of S. purnifolia with exclusively uniseriate rays. Scale bars $=100 \mu \mathrm{m}$.

tanakana), solitary and a group of 2-3 (S. coreana), and solitary and a group of 2-4 (S. purnifolia) (Fig. 2A-D). The highest number of vessels per millimeter is found in S. purnifolia $\left(198.09 \pm 16.98 / \mathrm{mm}^{2}\right)$ followed by $S$. coreana $(111.64 \pm 11.02 /$ 
Table 4. Pearson's correlation coefficients between different wood features in Symplocos species.

\begin{tabular}{|c|c|c|c|c|c|c|c|}
\hline & $\overline{\mathrm{VN}}$ & $\mathrm{VC}$ & $\begin{array}{l}\text { VD1 } \\
\end{array}$ & VD2 & $\mathrm{RN}$ & TW & $\overline{\mathrm{BP}}$ \\
\hline $\mathrm{VN}$ & & & & & & & \\
\hline $\mathrm{VC}$ & $-.774 * *$ & & & & & & \\
\hline VD1 & $-.750 * *$ & $.689 * *$ & & & & & \\
\hline VD2 & $-.778^{* *}$ & $.592 * *$ & $.716^{* *}$ & & & & \\
\hline $\mathrm{RN}$ & $-.809 * *$ & $.667 * *$ & $.730 * *$ & $.715 * *$ & & & \\
\hline TW & $-.453 * *$ & $.434 * *$ & $.392 * *$ & $.383^{*}$ & $.371^{*}$ & & \\
\hline BP & $.455^{* *}$ & $-.412 * *$ & $-.389 *$ & $-.481^{* *}$ & -.196 & -.287 & \\
\hline
\end{tabular}

$\mathrm{VN}$, number of vessels (/mm); VC, vessel circumference; VD1, vessel diameter parallel to ray; VD2, vessel diameter perpendicular to ray; $\mathrm{RN}$, number of rays (/mm); TW, tracheid wall thickness; BP, bordered pit.

$* *$ Significance $=0.01, *$ Significance $=0.05$.

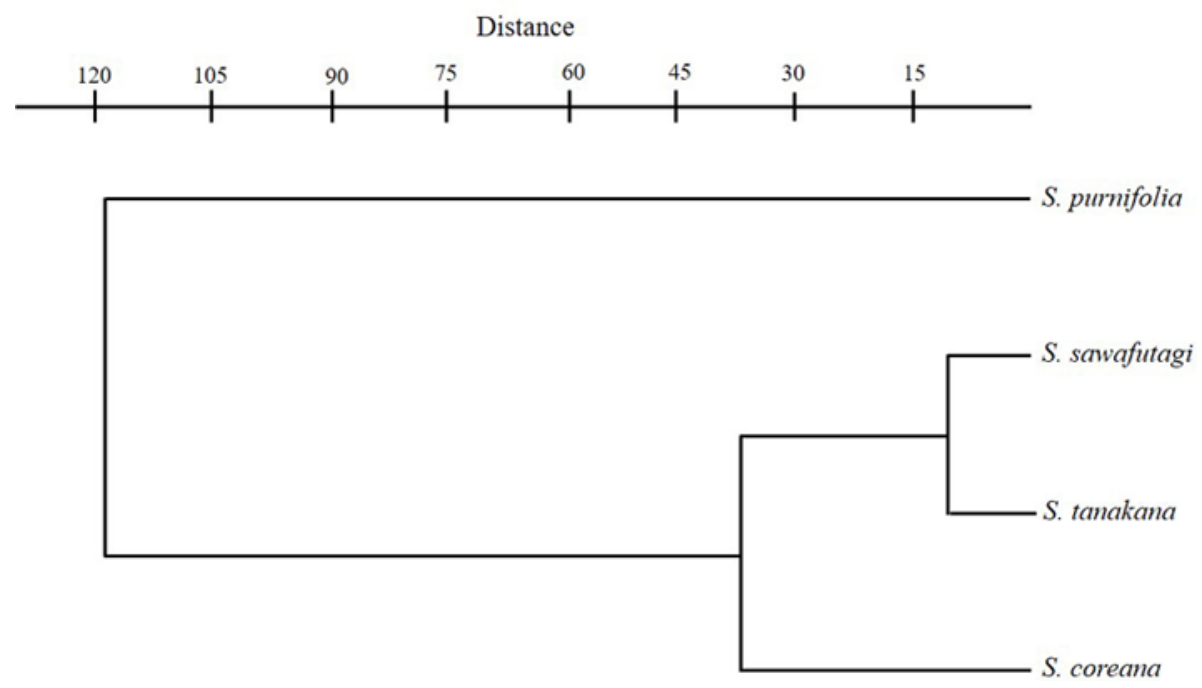

Fig. 6. UPGMA (unweighted pair-group method with arithmetic mean) phenogram based on wood variables of Symplocos species.

$\mathrm{mm}^{2}$ ) and the fewest number is counted in S. sawafutagi (83.09 $\pm 7.8 / \mathrm{mm}^{2}$ ). The perforation plates are the scalariform type with more than 40 bars and inter-vessel pits are scalariform or oppositely arranged (Fig. 3A, B). Correspondingly, $S$. purnifolia with the highest number of vessels per area has smaller vessel sizes in terms of circumference and diameter in both planes (Table 2).

The fibers are thick-walled without spiral thickenings $(S$. coreana, $S$. tanakana, and $S$. sawafutagi) or fine spiral thickenings (S. purnifolia) in the internal wall. In all species fibers are non-septate and the bordered pits are circular with a slit-like aperture in both on radial and tangential walls. The bordered pits are comparatively larger by diameter $(5.44 \pm$ $0.56 \mu \mathrm{m})$ in $S$. purnifolia than the other three species. Furthermore, three types of ray cell composition: procumbent body cells, upright cells, and square marginal cells, are found in $S$. tanakana, S. sawafutagi, and $S$. coreana while $S$. purnifolia comprised only procumbent and square cells mixed throughout the ray (Fig. 3C, D). Axial parenchyma is scanty diffuse and scanty paratracheal and septate (Figs. 2A-D, 4A, B). The rays are uni- to- biseriate in S. tanakana, uni- tomultiseriate with a maximum of three cells thick (triseriate) in $S$ sawafutagi and S. tanakana, and exclusively uniseriate in $S$. purnifolia (Fig. 5A-D).

One factor ANOVA was performed on seven quantitative traits and the differences between species are found to be highly significant (Table 3). Pearson's correlation coefficient also indicated a significant correlation between wood variables (Table 4). The cluster analysis based on the paired group (UPGMA) algorithm using the Euclidean similarity index clearly differentiates $S$. purnifolia from the rest in the taxa representing the first separated branch in the phenogram (Fig. 
6). Among the remaining three taxa $S$. coreana alienated first while $S$. tanakana and $S$. sawafutagi remain together in the subcluster.

\section{Discussion}

The result of this study indicated that Korean Symplocos are comparatively indistinguishable in terms of their qualitative wood features except for exclusively uniseriate rays and narrow vessels present in S. purnifolia instead of uni- to- multiseriate rays and wide vessels present in other three species. However, discrepancies are observed in quantitative variables such as vessel number per square millimeter, vessel size, and ray density. The vessel density of $S$. purnifolia (highest among four species) is more than two times higher than the $S$. sawafutagi (lowest among four species) and S. tanakana. On the other hand, vessel size is likewise reverse to the vessel number per $\mathrm{mm}^{2}$ i.e., vessel circumference and diameter in both planes of S. sawafutagi and $S$. tanakana is almost twice a larger than $S$. purnifolia. Similarly, the ray density is comparatively higher in S. sawafutagi and S. tanakana than S. purnifolia . In terms of vessel number per $\mathrm{mm}^{2}$ and vessel circumference, $S$. coreana lies in between $S$. tanakana and S. purnifolia, but in terms of ray density, it is closer with S. purnifolia.

The differences in quantitative wood variables such as vessel number per $\mathrm{mm}^{2}$, vessel circumference, and vessel diameter including ray width and ray cells in the radial section between the species of section Palura and S. purnifolia can be interpreted based on the sectional division. Although we only used $S$. purnifolia of the section Lodhra, the wood of this species is well differentiated from section Palura by exclusively uniseriate rays with only procumbent and square cells mixed throughout the ray. In addition, fine spiral thickenings are observed in vessel and fiber walls of $S$. purnifolia but these structures are lacking in all species of Palura included in this study. Yamauchi (1979) reported the wood anatomy of nine Japanese species and based on the obtained results she concluded that Japanese Symplocaceae could be divided into two genera, Dacalix Lour. consisting of evergreen species with axillary inflorescence and Palura consisting of deciduous species with terminal inflorescence. Although we may not agree with this arbitrary generic discrimination based only on the wood anatomy our results on deciduous and evergreen Symplocos is congruent with Yamauchi (1979) in terms of vessel density, size, and vessel and fiber wall thickenings.

Concerning the three species of section Palura, S. coreana exhibited some differences in wood variables with $S$. tanakana and $S$. sawafutagi in respect of higher vessel density, smaller vessel size, and lower ray density whereas later two species are almost identical in their wood anatomical features and remain closer in UPGMA phenogram (Fig. 6). Furthermore, these three species showed several morphological similarities including deciduous leaves, paniculate inflorescence, polygamous flower, bilocular ovary, and orbicular fruits (Ohwi, 1965; Soejima and Nagamasu, 2004; Chang et al., 2011, Kim and Kim, 2018). Only a few morphological differences displayed by $S$. coreana with $S$. tanakana, and $S$. sawafutagi include broadly obovate leaf lamina with coarsely serrate margin and bluish black fruit color instead of usually narrower, obovate to oblong leaf lamina with small and incurved toothed margin and bluish or black fruit (Ohwi, 1965; Chang et al., 2011; Kim and Kim, 2018). It has been suggested that some quantitative variations in the wood anatomical structures can be influenced by the growing conditions of the plant species (Baas, 1973; Carlquist, 2001; Campbell et al., 2016). Symplocos sawafutagi and S. tanaka which were collected form Pyeongchang-gun, Gangwon-do and Shinan-gun, Jeollanam-do, respectively, preferably grow deep in the forest with low sunlight whereas $S$. coreana which was collected form Miaksan, Seogwip-si, Jeju-do (in Korea this species only found in Jeju-do) usually prefer the edge of the forest with high sunlight. Thus, slight variations found in the wood of $S$. coreana can be explained based on the fitness of this species to the growing conditions. Likewise, $S$. purnifolia, sampled from Jeju-do, had the highest vessel density and smallest vessel sizes among the four species also preferably grow on the edge of the forest.

In conclusion, this wood anatomical study evidently offers an additional remark to differentiate $S$. prunifolia with other Korean Symplocos species. Some quantitative wood variables, on the other hand, distinguished S. coreana from S. tanakana and $S$. sawafutagi although an alternative explanation of environmental condition is prevailing. Based on the wood anatomy we are still unable to differentiate $S$. tanakana and $S$. sawafutagi as these two species are very similar in other morphology and also problematic in taxonomic nomenclature (see Ohwi, 1965; Korea National Arboretum, 2017). We believe that these results certainly provide a basis for further studies on the interspecific variation of Korean Symplocos. However, the number of species was very low and the wood samples used were juvenile, and thus any interpretation made on this basis could be arbitrary. Further studies considering as many taxa as possible and using mature wood materials certainly be helpful for resolving taxonomic problems in the genus.

ORCID: Balkrishna GHIMIRE https://orcid.org/0000-00022169-1280; Beom Kyun PARK https://orcid.org/0000-0003- 
1894-3296; Seung-Hwan OH https://orcid.org/0000-00032190-0967; Jaedong LEE https://orcid.org/0000-0002-66329058; Dong Chan SON https://orcid.org/0000-0002-6773-0580

\section{Acknowledgments}

This study was financially supported by the project 'Silvics of Korea (KNA1-1-18, 15-3).'

\section{Conflict of Interest}

The authors declare that there are no conflicts of interest.

\section{Literature Cited}

Baas, P. 1973. The wood anatomical range in Ilex (Aquifoliaceae) and its ecological and phylogenetic significance. Blumea 21: 193-258.

Baas, P., P. M. Esser, M. E. T. van der Westen and M. Zandee. 1988. Wood anatomy of the Oleaceae. IAWA Bulletin 9: 103182.

Baas, P., E. Wheeler and M. Chase. 2000. Dicotyledonous wood anatomy and the APG system of angiosperm classification. Botanical Journal of the Linnaean Society 134: 3-17.

Brand, A. 1901. Symplocaceae. In Das Pflanzenreich. Engler, A. (ed.), Engelmann, Leipzig. Pp. 1-100.

Campbell, G., G. R. Rabelo and M. Da Cunha. 2016. Ecological significance of wood anatomy of Alseis pickelii Pilg. \& Schmale (Rubiaceae) in a tropical dry forest. Acta Botanica Brasilica 30: 124-130.

Caris, P., L. P. R. Decraene, E. Smets and D. Clickemaillie. 2002. The uncertain systematic position of Symplocos (Symplocaceae): evidence from a floral ontogenetic study. International Journal of Plant Sciences 163: 67-74.

Carlquist, S. 2001. Comparative Wood Anatomy: Systematic, Ecological and Evolutionary Aspects of Dicotyledon Wood. 2nd ed. Springer-Verlag, London, 448 pp.

Chang, C. S., H. Kim and K. S. Chang. 2011. Illustrated Encyclopedia of Fauna and Flora of Korea. Vol. 43. Woody Plants. Ministry of Education Science and Technology, Seoul, 511 pp.

Cronquist, A. 1981. An Integrated System of Classification of Flowering Plants. Columbia University Press, New York, $1262 \mathrm{pp}$.

Esteban, L. G. and P. de Palacios. 2009. Comparative wood anatomy in Abietoideae (Pinaceae). Botanical Journal of the Linnean Society 160: 184-196.

Fritsch, P. W., L. M. Kelly, Y. Wang, F. Almeda and R. Kriebel.
2008. Revised infrafamilial classification of Symplocaceae based on phylogenetic data from DNA sequences and morphology. Taxon 57: 823-852.

Gasson, P. 1994. Wood anatomy of the Sophoreae and related Caesalpinioideae and Papilionoideae. In Advances in Legume Systematics, Part 6, Structural Botany. Ferguson, K. and S. Tucker (eds.), Royal Botanic Gardens, Kew, London. Pp. 165203.

Gasson, P. 1996. Wood anatomy of the tribe Swartzieae with comments on related papilionoid and Caesalpinioid Leguminosae. IAWA Journal 17: 45-75.

Hammer, Ø., D. A. T. Harper and P. D. Ryan. 2001. PAST: Paleontological Statistics Software Package for education and data analysis. Palaeontologia Electronica 4: 1-9.

Klaassen, R. K. W. M. 1999. Wood anatomy of the Sapindaceae. IAWA Journal Supplement 2: 1-214.

Kim, J. S. and T. Y. Kim. 2018. Woody Plants of Korean Peninsula. Dolbegae, Paju, 688 pp. (in Korean)

Korea National Arboretum. 2017. Checklist of Vascular Plants in Korea. Korea National Arboretum, Pocheon, 1,000 pp.

Lens, F., J. Schönenberger, P. Baas, S. Jansen and E. Smets. 2007. The role of wood anatomy in phylogeny reconstruction of Ericales. Cladistics 23: 229-294.

Malécot, V., D. L. Nickrent, P. Baas, L. van den Oever and D. Lobreau-Callen. 2004. A morphological cladistic analysis of Olacaceae. Systematic Botany 29: 569-586.

Nagamasu, H. 1993. The Symplocaceae of Japan. Contributions from the Biological Laboratory, Kyoto University 28: 173260.

Nooteboom, H. P. 1975. Revision of the Symplocaceae of the Old World, New Caledonia Excepted. Leiden University Press, Leiden, $335 \mathrm{pp}$.

Nooteboom, H. P. 2003. Symplocaceae. In The Families and Genera of Vascular Plants, Vol. 6. Kubitzki, K. (ed.), Springer Verlag, Berlin. Pp. 443-449

Noshiro, S. and P. Baas. 1998. Systematic wood anatomy of Cornaceae and allies. IAWA Journal 19: 43-97.

Ohwi, J. 1965. Flora of Japan II. Smithsonian Institution, Washington, DC, $1067 \mathrm{pp}$.

Olson, M. E. 2002. Combining data from DNA sequences and morphology for a phylogeny of Moringaceae (Brassicales). Systematic Botany 27: 55-73.

Oskolski, A. A. 1994. Wood anatomy of Araliaceae. Komarov Botanical Institute, St. Petersburg.

Oskolski, A. A. 1995 Wood anatomy of Schefflera and related taxa (Araliaceae). IAWA Journal 16: 191-215.

Oskolski, A. A. and P. P. Lowry. 2000. Wood anatomy of Mackinlaya and Apiopetalum (Araliaceae) and its systematic implica- 
tions. Annals of Missouri Botanical Garden 87: 171-182.

Schönenberger, J., A. A. Anderberg and K. J. Sytsma. 2005. Molecular phylogenetics and patterns of floral evolution in the Ericales. International Journal of Plant Science 166: 265-288. Soejima, A. and H. Nagamasu. 2004. Phylogenetic analysis of Asian Symplocos (Symplocaceae) based on nuclear and chloroplast DNA sequences. Journal of Plant Research 117: 199207.

van den Oever, L., P. Baas and M. Zandee. 1981. Comparative wood anatomy of Symplocos and latitude and altitude of provenance. IAWA Journal 2: 3-24.
Visscher, G. E. and R. Jagels. 2003. Separation of Metasequoia and Glyptostrobus (Cupressaceae) based on wood anatomy. IAWA Journal 24: 439-450.

Wang, C.-C. and C.-H. Ou. 2003. Wood anatomy of the Symplocaceae of Taiwan. Quarterly Journal of Forestry Research 25: $65-86$.

Yamauchi, F. 1979. Anatomical studies of woods in Japanese species of Palura and Dicalyx (Symplocaceae). Bulletin of the Natural Science Museum Series B (Botany) 5: 61-66.

Zhang, S. Y. 1992. Systematic wood anatomy of the Rosaceae. Blumea 37: 81-158. 